\title{
Gendered Managerial Discourses in Sport Organizations: Multiplicity and Complexity
}

\author{
Annelies Knoppers • Anton Anthonissen
}

Published online: 27 September 2007

(C) Springer Science + Business Media, LLC 2007

\begin{abstract}
The lack of women in senior management functions in sport may in part be attributed to dominant discursive managerial practices in sport organizations. The purpose of this study is to explore ways in which the discourses and their subtexts used by directors of Dutch national sport organizations to talk about their work, sustain homologous reproduction. Close reading of the transcripts of interviews by both researchers followed by a continuous cycle of data reduction and verification and researcher agreement enabled four dominant discursive themes to emerge. We show how an overlap of various discursive practices related to instrumentality, relationality, emotionality/passion and homogeneity strengthen the gendered nature of senior managerial work in large sport organizations.
\end{abstract}

Keywords Sport management · Managerial work · Gender

\section{Introduction}

Managerial work has changed a great deal since the beginning of the twentieth century; these changes include an increased emphasis on the need for managers to posses and use good communication and interpersonal skills. This change has often been associated with the feminization of management, with the creation of more women-friendly organizational cultures and managerial leadership styles, and with the necessity to employ more women managers (see Hearn 1999; Kerfoot and Knights 1998; Moore et al.

\footnotetext{
A. Knoppers $(\square) \cdot$ A. Anthonissen Utrecht School of Governance, University of Utrecht, Bijlhouwerstraat 6,

3511 ZC Utrecht, The Netherlands

e-mail: a.e.knoppers@uu.nl
}

2001; Wacjman 1998; for a discussion of this point). Such changes have, however, come about primarily at the middle management level where most women managers are located. Senior managerial work in most organizations, including that in sport, is still primarily a male domain (Acosta and Carpenter 2006; Claringbould 2006; Hughes 2004; Lapchick 2006). Researchers who have focused on the skewed gender ratio of the number of executive directors/senior managers in sport organizations have looked at ways in which these individuals explain their lack of women colleagues and/or have explored individual differences between men and women athletic directors (Fitzgerald et al. 1994; Hoeber and Frisby 2001; Sagas and Cunningham 2004; Whisenant et al. 2002; White and Brackenridge 1985). Shaw and Frisby (2006) however, have shown that gender not only shapes identities but is an axis of power that also plays an influential role in interactions, structures, and processes of sport organizations. Shaw (2006) focused on social processes in sport organizations and found that use of humor, dress codes and informal networking had gender subtexts that contributed to the gendering of sport organizations. The assumption that gender is an axis of power requires analyses therefore, that go further than liberal feminist approaches that see women as deficient, that assume equal opportunity structures are gender neutral, or cultural feminist perspectives that assume cultural differences, that is, that an increase in women can bring added value to male dominated organizations (cf. Meyerson and Kolb 2000). Analyses are needed that use a post structural approach. Such an approach seeks to deconstruct hegemonic assumptions about gender and to draw attention to the fluidity, multiplicity and complexities of discourses (Weedon 1997).

Several researchers have used a post structural approach to explore ways in which discursive practices of managerial 
work in sport organizations contribute to the skewed gender ratio. Discourse analyses can expose the gendered nature of current configurations of practice that exclude women (Martin 2006). For example, Shaw and Slack (2002) used an historical post structural analysis to explain why sport organizations currently favor certain forms of masculinities and discount or devalue expressions of most femininities. Not only are post structural analyses of sport organizations rarely conducted, even less attention is paid to analyzing managerial work with the use of such a perspective. Yet, scholars need to pay attention to the way those who hold a great deal of power in the sport world practice gender since they make decisions about funding, about the delivery of programs and services to athletes and coaches, about the selection and evaluation of personnel, and, about the mission, development of strategic change in both sport and the organization itself (Inglis 1997). The primary purpose of this paper therefore, is to use a post structural framework to examine dominant discourses that executive directors/senior managers of national sport organizations use to describe their work and to suggest ways in which these discourses and/or their subtexts may reinforce the skewed gender ratio and keep many women out. An understanding of these subtexts could be utilized to modify or disrupt those discourses, and subsequently, the gendered nature of organizational cultures.

Little is known about how senior managers or executive directors of (sport) organizations construct the cluster of skills that comprise their work (cf. Rutherford 2001). Various scholars (see for example, Acker 1990, 1992; Benschop 1996) have argued that the discourses that are used to describe such skills and organizational processes tend to be presented as gender neutral but often have invisible gendered subtexts. Hovden (2000) found that although the explicit selection discourses for members of national sport committees assumed equal opportunity for all qualified candidates regardless of gender, the subtexts of these discourses ensured that most women were excluded from consideration. Congruencies between heroic qualities that were associated with men and images of an "ideal committee member" of national sport organizations resulted in the selection of relatively few women. Gendered subtexts are not only confined to selection discourses however, but play a role in discourses that describe jobs in sport in organizations as well.

Shaw and Hoeber (2003) explored the gendering of discourses used to describe positions of leadership used by senior sport managers, coaches and teachers, and regional development officers in three English national sport organizations. They found that discourses describing the tasks of senior management contained various gendered subtexts. Jobs associated with women and with discourses of femininity tended to be marginalized in these sport organizations while senior management positions tended to be valorized and associated with discourses of masculinity. Exceptions were discursive practices pertaining to skills associated with jobs in human resources. These were situated within discourses of femininity and were perceived to make a valuable contribution to the organization. Although Shaw and Hoeber are one of the few to explore the discourses about the gendering of positions of leadership in sport organizations, their analysis focused on the ways that those in various jobs described these positions. They did not, however, look at how managers in sport organizations described their own work responsibilities and how these responsibilities were gendered.

We theorize gender as "situated social practice" that is "rooted in the doing and saying of organizational actors" (Poggio 2006, p. 225). Connell $(1987,2005)$ has argued that current ways of doing gender are sustained and/or challenged by configurations of practices. Doing gender consists of engaging in actions that are part of social processes. These actions include practices of power that support or challenge domination of men and subordination of women, practices of production that reinforce and/or challenge a gendered division of labor, and practices of cathexis that sustain gendered constructions of sexual desire and emotional commitment. In the current study, we reveal configurations of practice that gender senior managerial work by exploring dominant discourses and their gendered subtexts that executive leaders of sport organizations use to describe their work and skills.

\section{Method}

\section{Participants}

This study is the first empirical study that is part of a larger study in which we explore the nature of the connections, if any, between meanings given to sport/physicality, gender, and managerial work in different types of nonprofit organizations. The population in the current study, consists of executive directors/senior managers who work for one of the 50 large sport organizations in The Netherlands. At the time of the study, White men held all these positions. We interviewed senior managers of these organizations until the saturation point was reached, that is, new interviews did not yield additional information. The resulting sample consisted of 12 executive directors/senior managers. All are White and ranged in age from 47 to 61 years. One identified himself as gay. At the time of the interviews, seven of the senior managers were executive directors of national sport associations; two were in charge of national governmental departments responsible for sport; and, three others were executive directors of national multiple sport organizations. 
Since job titles differ per organization we use the terms (executive) director and (senior) manager for them all and interchangeably.

\section{Procedures and Data Analysis}

The semi-structured interviews lasted about $90 \mathrm{~min}$. In the current analysis we focus on the data in which these men talked about their managerial work, that is, their responsibilities, daily routines, career possibilities, required skills and the relationship between their managerial work and domestic life. All data were analyzed with the use of a discourse analytic method (see Alvesson and Skoldberg 2000; Fairclough 1995). Close reading of the transcripts of the interviews by both researchers allowed several related discursive themes to emerge that appeared repeatedly in the ways in which these managers talked about their work related to the focus and research question of this study. Subsequently, we looked for evidence and counterevidence that confirmed or challenged the formulation of the theme and refined the themes until both researchers agreed on the themes. This cycle of data reduction and verification was a continuous process that enabled four dominant discursive themes to emerge that the senior managers drew on consistently. These themes do not represent exhaustive or mutually exclusive categories but signify our attempt to identify salient grounded meanings held by the managers. The reliability of the analytical procedure therefore lies in the rigorous adherence by which the described method was followed and not in intercoder reliability as might be the case in more semiotic or categorical type of analyses. In addition, it is the nature of the themes rather than the precise number of managers who made a specific statement that is central to a method situated within a post structural framework. In our presentation of the results we draw on the scholarly literature to suggest gender subtexts of each of the discourses that may contribute to the exclusion of women from these and similar positions. Since the perspectives of the directors on these topics were similar and to avoid identifying them, we do not identify them or their organizations in our presentation of the results. We use quotations that best illustrate the viewpoints of these managers.

\section{Results}

Although our original intent was to apply Connell's (1987, 2005) framework directly to our data and group the themes under the appropriate configuration (production, cathexis, power), we found that letting the data speak for itself first and then exploring how the resulting discourses may reflect configurations of practice as described by Connell, did better justice to the data then trying to force the data into predetermined configurations. The results indicate that these directors employ three explicit overlapping discourses and one implicit discourse. They use discourses of instrumentality to describe the ways they do business. They emphasize that relating to others constitutes a large part of their job (discourses of relationality). In addition, they use discourses of emotionality to describe their passion for the job and for sport. We also note the presence of an implicit discourse of homogeneity or male homosociality. As we shall show, there was much slippage and many contradictions in the ways the managers used these themes to describe their work.

\section{Discourses of Instrumentality}

\section{Toughness and Perseverance}

These directors spend much time developing strategies and policies that ensure that their organization follows the desired course, reaches its stated objectives and has the financial and human resources to do so. They accomplish this by attending many formal and informal meetings and events, by managing employees in an informal way, by networking and by using their persuasive power.

The directors who were part of the current study emphasize that their work encompasses many areas and requires various skills. They must ensure a growth in the number of participants in their sport, create conditions so that elite athletes/teams can perform in an outstanding manner in international competitions, guide processes of professionalization of their largely volunteer organization, and, must be competitive and tough. A director sums it up as follows: "The essential competencies [of this job] have shifted from developing and implementing your vision to focusing on quantifiable results, being goal driven, showing initiative, and, getting sponsors." Efficiency is seen as important. As one director says: "I continually ask "How are we efficient and how are we inefficient?"”

Since sport associations and organizations receive their funds from membership fees, sponsors and government subsidies, these senior managers compete with each other for scarce economic (financial) and human resources (athletes, fans and volunteers) while they also acknowledge that "in the sport world you need each other." A manager describes the sport world as a "jungle... [in which] justice or truth do not rule but the person with the biggest mouth is most powerful... the rule of the strongest is the norm..." $\mathrm{He}$ justifies this practice because "the need to win is part of sport...." These senior managers present themselves as very competitive and as winning in this jungle. They achieve results by being in control, being stress resistant, and by exuding self-confidence in all situations. They cannot show 
uncertainty or ignorance. A manager points out that the demands on directors are increasing. "We have to bring in more financial resources, we have to manage processes of change that require us to be present all the time and you are and have to be a role model... so you show up even when you are ill." Some state that the perseverance that they need to perform well was developed during their sport history:

If something has to be done, we do not think about it. We just do it. That typifies someone with a sport background, I think. We focus on results. I am only satisfied with first place. I give $100 \%$ and am not satisfied with second place... second place can be honorable but I find it difficult.

These demands are presented as gender neutral because "anyone can meet them" or "a woman can do this too."

Yet, the toughness and perseverance that are perceived to be required to meet organizational goals have gender subtexts. For example, these directors use their own sport involvement to emphasize that they possess the required toughness. Several recount how they currently participate in matches or competitions in their sport in order to "gain respect by showing you have the guts to do so." These connections tend to be linked implicitly to men's-and not women's - sport. By their presence at and participation in boys' and men's events, these managers implicitly and explicitly legitimize and promote male sport. They are therefore more likely than women to reap the benefits of this investment in social capital (cf. Sagas and Cunningham 2004). Moreover, if such practices are seen as 'obligatory' and are seen to enhance a director's position with volunteers, then such discursive practices may place women in an ambiguous position. The meanings assigned to the participation of a woman manager in a men's or women's sport event may be quite different than those attributed to the participation of male directors. Women sport managers may find personal participation in men's sport extremely difficult, although they can attend top events as a spectator and as part of the sport network. If proof of desired competitiveness and toughness is implicitly linked to men's sport, the candidacy of women for high-ranking positions in sport organizations may not be taken very seriously. The overall marginalization of women's sport may also mean that intensive involvement of women senior managers in that sport is largely invisible.

\section{Availability}

These directors are at the top of the career ladder for those in sport management. Their only possibilities for moving up are positions outside of the sport area. In general they show little interest in moving to other jobs outside of sport however. This may be in part due to their perception that their work in sport hampers their job applications else- where. A director explains that "too much sport on your cv is bad for your career." These directors may be seen as heroes within the sport world and as 'dumb jocks' outside of it. The dominant body-mind dualism in the nonsport world may keep sport managers within the sport world and has consequences for their discursive managerial practices. Kanter (1977) has shown that those with limited possibilities in vertical advancement tend to invest a great deal in the organization themselves. This is true of these men as well, as they spend many hours at their work. They devote most of their energy to their jobs and being available most of the time. They work 50-60 h/week and rarely call in sick. A director typifies this practice by exclaiming that "I've only called in sick two days in the past 18 years that I've worked here!" Being physically present suggests individual competence and commitment. A director proudly says that "if I am not present [in the building], they say "where is he??!!!"'

These directors work hard to ensure their domestic life does not visibly interfere with 'business practices.' They are very clear that they have their domestic life under control. Their partners do "not mind" that these managers work so many hours; most partners have chosen a part time job in order to ensure that at least one person is at home with the children. As a director explains: "This [job] does not permit me to have many responsibilities at home... I am not home much... I travel a great deal, including internationally. You have to have a partner who can be there for the children." At the same time however, these directors present themselves as responsible parents who do their share by taking their children to school on certain days and/ or taking out the garbage. Often they try to combine the time they spend with their children with their job. They take their children to major sport events and/or coach their children's teams on the weekends. In this way, they can simultaneously fulfill domestic obligations and be "seen" in the sport world by the many volunteers.

The subtext of their representation of their domestic life implies that commitment to an organization requires a containment of domestic responsibilities so that they do not interfere with paid work. This assumption of almost total availability of those in positions of leadership is not confined to sport but tends to be seen as a self-evident requirement of senior managerial work (see for example, Acker 1990; Lyon and Woodward 2004; Wacjman 1998). Male managers show they are heroic and in control by working many hours and by having someone else take responsibility for their family life. Connell $(1987,2005)$ has shown how a configuration that requires long work days/ weeks strengthens and institutionalizes the gendered division of labor in heterosexual domestic arrangements and in organizations themselves (relations of production). The domestic arrangements of men have become the norm for managers although these arrangements are seen as being 
neutral and gender free. Women's domestic arrangements are often perceived to undermine women's willingness to work many hours and to be available at all times (see for example, Kvande and Rasmussen 1994; Lyon and Woodward 2004; McKay 1997). This $24 / 7$ availability is a construction, however, and its necessity for productivity is questionable. It has, however, been defined as proof of being in control and being tough.

\section{Impression Management}

Since the leadership of most sport clubs in The Netherlands is in the hands of volunteers, these managers spend a great deal of time gaining their trust. They do so by 'being seen' at club events around the country, by either coaching or participating in the sport themselves in order to gain consent for their policies, and by creating the 'right' image. Impression management is a constant theme in the ways these managers describe their work and responsibilities. A director argues that an emphasis on the importance of image is increasingly a part of senior sport managerial work. "You create an image of your organization, your product and services by the way you look." These directors work on this image in several ways.

They deliberately choose their clothes depending on the situation. They wear casual clothes when visiting a sport club and working with volunteers and a three-piece suit when talking to sponsors and politicians. They believe that wearing casual clothes can flatten hierarchies, but at times, other clothes are needed. A director explains his rules for clothing: "When I travel with [a high government official] to another country, I will bring my best suits... but when visiting the sport fields you must wear a sweat suit." Another explains his strategy: "It does not work if I give a speech somewhere and wear a three piece suit while everyone is in sport clothes ... so I strategically select what I wear." In other words, these men use their dress to create a masculinity that conforms to that what they perceive is most desirable in a specific situation. As Shaw (2006) has pointed out, the way in which a person dresses in the sport world may be used to confirm gender status or challenge it. A woman and man senior manager may both wear a sweat suit when visiting sport clubs. We know little of the extent to which the same piece of clothing may be seen in gendered ways. Possibly meanings given to men in sweat suits in the sport setting may be different than those given to women especially since women's sport and men's sports tend to be given different meanings (Messner 2002). However, as Shaw points out the other form of dressing employed by managers, the three-piece suit, is a strong marker of senior managerial masculinity in sport.

Part of creating the right image means paying attention to how the body is judged. These managers insist they must always look fit, alert and healthy. As one says "Being considered fat is bad for the image of the organization." Another says: "If I were 40 pounds overweight and you could see rolls of fat and I smoked in public... that would not be right... lots of people would have trouble with that and I would lose my credibility." These directors not only have to have a healthy and fit image but they also argue that they "have to be healthy and fit to be able to cope with the stresses and pressure of this job." They argue that the long hours and their decision-making responsibilities require that they have the stamina to work 12-h days and weeks of 50 $60 \mathrm{~h}$. A director summarizes the relationship between image and connecting with volunteers: "You must look fit and attend events to show you know what you are talking about... the job is never ending." This modeling of fitness and of sport participation therefore, plays a strong role in the way these directors engage in impression management. A director explains: "This is an organization with more than 700,000 members and 1,800 clubs... the importance of your image increases daily."

This manner of doing impression management has gendered subtexts (see for example, Bird 1996; Martin 2001, 2003; Wacjman 1998). Such practices mark women as different; in a world that is already seen as men's world, informal image codes often place women in a position of outsider and "other" regardless of their affiliations and appearance. McDowell (1997) argues that women are at a disadvantage in occupational forms where personal appearance and bodies are defined as being crucial for success. Connell (2005) contends that: "Gender is social practice that constantly refers to bodies and what bodies do" (p. 71). This would include the ways people engage in impression management. Processes of inclusion in managerial circles may therefore require embodiment in ways that are congruent with this way of practicing masculinity.

\section{Summary}

This discourse of instrumentality is therefore based on achieving results using competitiveness, time investment and impression management. As such, this configuration of gendered practices can play a role in strengthening the current division of labor that implicitly may privilege managerial men and men's assignment to senior managerial work in sport. Goal achievement means however, that these directors must possess excellent communication skills.

\section{Discourses of Relationality}

All of these directors claim that interacting with others comprises a large part of their job. The ways in which the directors describe their interactions with others varies by the group with which they interact: their employees, 
volunteers in their sport(s), and senior managers or directors of other sport organizations or governmental agencies. The major emphasis in their descriptions of their interactions is however, on their excellent communication skills.

Close readings of their descriptions of their interactions, especially with employees, reveal a paterno-authoritarian theme (Collinson and Hearn 1996). These men describe themselves as having a "people orientation" in their work and as having an informal leadership style. They try to pay attention to their employees and events in their lives and thus stimulate their productivity. Their doors are "always open." As a man describes: "I engage in management by walking around. And I try to delegate a lot to enable people to grow in their jobs." Another says "I try to work side by side with my staff." The managers strive to let their employees work independently but also give them clearcut assignments. As one manager explains: "I give them all the necessary information so that they can come to the same conclusion as I do." A manager describes his working style as follows: "Being involved, consulting and communicating with others... not being bossy but I do want to have it done my way because I want to realize my vision for this organization." These quotes not only show an emphasis on an informal leadership style but also typify the implicit authoritarian overtones of their descriptions of manageremployee relationships. One director admitted that "there are times when you have to show authoritarian behavior because decisions have to be made and you cannot engage in endless discussions ... Of course I always try to get people to say what I want to hear." The others openly distanced themselves from authoritarian labels and practices although they did engage in it implicitly. As one director put it "I am a democratic leader. I do not like authoritarianism although I am very clear in what I want."

This infrequent explicit use of an authoritarian discourse may be due to shifts in dominant managerial discursive practices. Authoritarian discourses are generally considered to be out of fashion (Kerfoot and Knights 1998; McDowell 2001). Consequently, senior managers may avoid this discourse when they are asked to describe what they do. Wetherell and Edley (1999), who studied the ways men represent themselves in interviews, point out that professional men tend to talk about their work in ways that allows them to create self-representations of a masculinity that reflect them in a positive way. If authoritarianism has a negative connotation, managers may not use such discourses to describe how they do their work. Instead they explicitly stress their use of what Collinson and Hearn (1996) describe as a paternal discourse although their use of it often has implicit authoritarian overtones as the previous section has shown. Whereas management used to be primarily characterized by autonomy and authoritarianism, it now obviously requires instrumental connectedness as well (Hatcher 2003).
It would seem that this shift from authoritarian to paternalist discursive practices would allow more women to engage in managerial work. The emphasis on showing empathy for and connectedness with employees and on communication skills may also reflect a feminization of (sport) management. Various researchers (Kerfoot 1999; Riley 2001; Wacjman 1998) have argued, however, that many male managers have appropriated these social skills for their instrumental value and that they use this skills to stay in control. This is true of these managers as well. They use these skills to empower employees to reach the goals the directors or managerial team has set for them. Ashcraft (2005), in a study of masculinities and discourses used by airline pilots, suggests that the use of informal leadership skills "reflects the way a savvy man in today's world gets people to perform for him" (p. 81).

These directors frame their use of people skills as their personal choice and preference and not as formal skills that they have had to learn and/or were required to develop by their organization. The manner in which the directors present themselves in their relationship with employees has heroic overtones, as they emphasize their choice to demonstrate empathetic behavior and excellent listening skills in communicating and mentoring their employees. This discursive practice is congruent with a human resource discourse in which directors or managers see themselves as acting in best interests of the organization and employees and use intimacy to keep control (Kerfoot and Knights 1998; Moodley 1999). Their use of these skills is a way to exercise their power. They do so by "emphasizing the moral basis of cooperation, the protective nature of their authority, the importance of personal trust relations and the need for employees both to invest voluntarily in their work task and to identify with the company" (Collinson and Hearn 1996, p. 157). This configuration of power allows the directors to position themselves as being in charge (cf. Connell $(1987,2005)$.

The relational discourse used by these sport managers is gendered in various and contradictory ways. The sensitivity that these directors say is needed to work with their employees tends to be stereotyped as a skill associated with women (see also Shaw and Hoeber 2003). Several directors involved in this study acknowledge that women probably have "developed their sensitivity skills more than men." This suggests that women could be ideal candidates for positions of executive director in these sport organizations (Moore et al. 2001). This is not necessarily so. The directors involved in this study contend that they posses the necessary expertise to do the job well and that women are not necessarily needed to fill such positions.

Similarly, Wacjman (1998), who studied women and men managers in five multinational companies, found that the emphasis on interaction abilities at all managerial levels has meant that male managers have added these skills to 
their repertoire so that women are not really needed to contribute these skills to organizations. Men tend to be rewarded for choosing, learning, and mobilizing these skills as occupational resources. Moreover, many male managers use these skills in an instrumental way; that is, they are measured by the "yardstick of utility" (Kerfoot 1999, p. 188). This is different than using these skills for the sake of the employee.

In addition, the possible need for an increase in women managers due to the increasing emphasis on the use of relational skills often pertains merely to this aspect of the job. Shaw and Hoeber (2003) found that those working in sport organizations valued the association between women and human resource discourses only when a job was confined to that. Discourses describing the work of senior managers tend to place a much greater emphasis on business leadership than on skills associated with "femininity" and therefore enable male managers to create a practice that, although it uses skills that are associated with women, is associated with masculinity because of the context in which these skills are used. At the same time, these directors also present themselves as heroic because of their use of 'people skills' and as autonomous professionals (cf. Ashcraft 2005; Wetherell and Edley 1999). This heroism may allow them to acknowledge the ambiguity of the relational discourse in which normative perceptions of women assume they have better skills.

\section{Discourse of Emotionality or Passion}

Their work, their private lives, and their passion for sport are synonymous for these directors. Their private lives are often lived on the sport field or in the gymnasium as they coach, participate and attend sport events. They insist that this passion, their personal sport history, and their current sport involvement are job requirements. "You have to assume that those for whom you work [volunteers] are passionate about the sport. If you do not have that passion then you miss a necessary skill: that is, knowing what is going on." Another uses passion to explain the dominance of men in leadership positions in sport: "Men stand in line to do volunteer work in sport; you have to have a passion for the sport and there are more men [than women] who have that." Another director explains the necessity of having a history in competitive sport: "You have to have a background in this sport so people know you and so you know the emotional side." In addition, most of these managers attribute their people skills, their perseverance and their abilities to work with others to their team sport experiences. They work hard to impress volunteers with their involvement and with their fitness. In other words, they embody their sport and job with passion. Connell (1987, 2005) has called this gendered configuration of emotional commitment, cathexis. This passion or emotional commitment of these men is also exemplified by their involvement and their long workdays.

This discourse of managerial passion is complex, however, and is not totally unique to sport (Peters and Waterman 1982; Hatcher 2003). Hatcher argues that passion has now become a necessary quality that enterprising managers must display. She contends that although rationality has been considered a key tool in modern management, managers now need to be passionate about both the job and the primary activity of the organization. This passion must not be disordered, however, but be controlled. This emphasis on control allows the use of this discursive practice to be associated with masculinities instead of femininities. In this manner these configurations of cathexis are gendered.

This control is not always evident in the world of sport governance and management, however. The directors involved in the current study mention incidences and decision-making processes, which according to them, would not be tolerated in the nonsport world. Several directors describe scenes in which members of their governing board "literally fight with each other." These managers attribute such occurrences in the sport world to the passion and emotion that sport evokes. Outside of sport, a lack of emotional control is often attributed to women. Possibly then, these uncontrolled displays of passion are not constructed as feminized behavior in sport organizations because they occur in a world that is dominated by men and their discursive practices (cf. Dellinger 2004). In addition, the aggression with which this passion is displayed may be constructed as a masculine practice within this sport context.

Although women may also have or display a passion for sport, this discourse may often have a gendered subtext. Women's discursive practice of emotionality or passion for sport may be quite different than that of male directors. Women may engage in this discourse by attending many sport events and by using masculinist discourses to describe their sport experiences. They do not, however, have a shared history with their male colleagues of participation in men's sport. Participation in physical fights or engaging in aggressive arguments during board or management team meetings may not be seen as suitable discursive practices of passion for women because of their gender. They may also be sanctioned as bad mothers or spouses if they distance themselves from domestic life to discursively practice passion for their sport similar to that of these managers (cf. Knoppers and Bouman 1998). In addition, little is known to what extent this display of passion may include girls and women's sport or that it must primarily center on men's and/or boys' sport. Possibly then, women may engage in discourse of passion similar to that used by male 
managers but it may be read in gendered ways. Further research is needed to explore the ways in which this configuration of cathexis is constructed as gendered and requires gendered (bodily) practices. This is not the only way in which these managers configured cathexis or emotional commitment however.

\section{Discourse of Homogeneity}

Descriptors of informal connections among men, such as "the old boys network" and "homosociality" (Bird 1996), cathexis (Connell 1987, 2005) and "affiliating masculinities" (Martin 2001), have drawn attention to the ways in which men associate with the "in group" and at the same time "differentiate themselves from other groups of men and from women" (Collinson and Hearn 1996, p. 159). Since these managers work in the world of sport, it is not surprising that male bonding plays a crucial role in the way these directors work although they profess not to see the gendered nature of these networks (cf. Shaw 2006).

While their immediate support comes from female administrative personnel and, with one exception, from their female spouses at home, the directors in the current study work primarily in a male homosocial world. The majority of the chairs of national sport governing boards, directors of other national sport organizations, key sponsors and political contacts, athletes, volunteers, coaches and administrators in Dutch sport are men (Claringbould 2006; Nuijten et al. 2004; Stol 1995). The male homosocial nature of their work world seems to be discursively irrelevant to these men. None of the interviewed directors mention the single sex nature of their work world but only identify their world as male when specifically asked. In response to this question a manager says: "Yes, it is a male world. If you go to a membership meeting of the Dutch National Olympic Committee, then you see 300 men and 10 women... I mention that fact [gender skewness] only when asked." This fits Martin's (2003) contention that many men may only be liminally aware of the homosocial nature of their world and tend to be nonreflexive about the resulting dynamics. A director says "I do not know why a woman would not feel at home in that world; I think it is a personal matter." Martin (2003) calls this liminality and argues that

Liminal awareness allows men (and women, in other circumstances) to act as they please without being concerned about the effects of their behavior on others. That is, if they believe their practices are not gendered, they can "honestly deny" acting in a gendered way, even if others see or experience them as doing so (p. 356).

This discourse of homogeneity or of homologous reproduction (cf. Kanter 1977), explicitly influences the exclu- sion of women, minorities, and marginalized men from positions of leadership in sport. It implies that managers must be like or engage in normative conceptions of White heterosexual men in order to succeed and that those who are excluded are themselves responsible for attaining positions of leadership in sport. As such, this discourse supports a gendered division of labor (cf. Connell 1987, 2005). The prevalence of this assumption among managers has been thoroughly documented in the scholarly literature (see for example, Acker 1992; Knoppers and Anthonissen 2005; Martin 2001, 2003; Wacjman 1998). Images of and meanings given to positions and tasks are assumed to be gender neutral and the associated discourses imply equal opportunity. The use of this discourse of homogeneity (and absence of a discourse of diversity) is therefore not unique to sport. It may however be stronger in sport organizations since the discourse about the primary activity (sport) also often implies equal opportunity (Hall et al. 1990; Knoppers and Anthonissen 2005; Knoppers 2006; McKay 1997). The use of a discourse of homogeneity reinforces a conservative gender order and masks inequality by stressing neutral meritocracy and individualism.

\section{Discussion}

The data show that senior managerial work in sport organizations is not constituted by a single discourse or by a unitary configuration of practices. Several of the discourses used by these managers are similar to those attributed to managerial work in general (Collinson and Hearn 1996; Knoppers and Anthonissen 2005). The use of relational and instrumental discourses by the senior managers in the current study for example, reflect paternoauthoritarian and entrepreneurial discourses of managerial masculinities as described by Collinson and Hearn (1996). This similarity of discourses across various types of organizations may in part be "due to a resonance between some forms of masculinity and bureaucracy, market capitalism and western conceptions of science" (Martin 2001, p. 611). This resonance suggests that management requires similar discourses of domination regardless of the primary activity of the organization. The language and metaphors that are used to constitute these managerial discourses, however, may be specific to a type of organization or occupational form (Ashcraft 2005). The managers in the current study, for example, take pains to show how well they relate to volunteers in the sport field, how they chose their dress to reflect their identification and why they need to appear at many sport events. Such activities and implicit requirements may be unique to sport.

The discourses presented by Collinson and Hearn (1996) do not capture all of the configurations that these directors 
or senior managers use to describe their work, however. Collinson and Hearn do not discuss discourses of homogeneity or of emotionality/passion. The discourse of homogeneity is an implicit discourse, however, and captures lack of responsibility instead of responsibility. This discourse may constitute a managerial practice in organizations that do not reflexively and strategically implement forms of management of diversity. Its implicit nature means that scholars and managers may not realize its presence although it manifests itself in explicit practices such as skewed gender and minority ratios. As we indicated earlier, discourses of homogeneity may be reinforced in sport organizations due to the prevalence of discourses of equal opportunity in sport (Claringbould and Knoppers 2007).

The primary activity of the organization also provides at least one other discursive practice, that of showing passion for sport. Although managers in nonsport organizations must now display passion as well, the passion for sport as primary activity may be configured differently than that in organizations where health care or education comprise the primary activity. Further research of managerial discourses needs to take into account that discourses not described in the literature may be part of the discursive repertoire of managers in a specific context and that those captured in scholarly research may manifest themselves in practices that are unique to the primary activity of an organization. The subtexts of those discourses may reveal configurations that add to and strengthen practices of exclusion.

These executive directors of sport organizations do not create a unitary discourse about managerial work but a multiplicity of contradictory and overlapping discourses that they mobilize to keep 'the other' out. This dynamic illustrates the Gramscian notion of appropriation of elements of marginalized groups that enhance domination by powerful social groups. As Demetriou (2001) explains the "ruling class is in constant mutual dialectical interaction with the allied groups and appropriates what appears useful and constructive for the project of domination at a particular historical moment; useless or harmful elements are subordinated/discarded because they have no historic value" (p. 345). Thus explicit authoritarianism is discarded and replaced by the use of relational skills and display of passion. Instrumental or business discourses are still required but primarily in concert with discourses of emotionality and relationality. Dominant discourses about sport and about managerial work have always been allied with constructions of desirable masculinities. Possibly in these contexts relationality and emotionality are not configured as discourses of femininity but as masculine practices.

The accumulated gendered subtexts of these discourses preserve, legitimize and naturalize the power and privileges of those already holding senior positions such as these managers. Their gender becomes their organizational resource (Acker 1992). These configurations of practices may influence organizational processes in sport and their gendering. They shape the gendered context in which organizational life takes place (Martin 2001). Although managerial work that emphasizes relational skills or displays of emotions is usually associated with women, the meanings given to both the context (sport), the type of position (senior manager) and to the gender of those occupying the position may have a multiplicative effect that makes this work a practice that is configured to support managerial masculinities. Although none of the practices excludes women entirely, each discourse has a gender subtext that creates or reinforces a culture that tends to exclude women as well as minorities and anyone who does not engage in these discourses or is not associated with them. Together they create powerful configurations that may be difficult to change.

Strategies and policies that are designed to shatter the glass ceiling of managerial work that do not take into account this multiplicity of discourses and their contextualization may therefore be destined to fail. Not a single practice but configurations of these practices may keep many women out of this work. These discourses also intersect with those that configure other social relations such as race, ethnicity and sexual preference. Little is known for example about the extent to which whiteness and managerial masculinities intersect to produce and reproduce these discourses in sport organizations. Further research is needed that explores these intersections.

One additional issue needs to be mentioned. The data from this study reflect ways in which these managers represented themselves to those who interviewed them. Specifically, the data do not reveal a specific type of male manager but describe the ways these men who direct sport organizations position themselves discursively with respect to their work As we indicated earlier in this paper, male leaders may represent themselves in ways that create heroic masculine forms of leadership (cf. Wetherell and Edley 1999).. As such these managers may use these interviews to construct themselves as heroic managers who excel in managerial work. Connell and Messcherschmidt (2005) suggest that "men can dodge among multiple meanings according to their interactional needs" (p. 841). Yet the representations were remarkably consistent across these interviews. Possibly these managers may position themselves vis a vis a perceived hegemonic form of managerial masculinity in sport organizations. Further research is needed to explore the ways in which discursive practices of senior managers reflect how they do gender. Martin (2006) suggests collecting stories in which managers and those who work for them describe how they practice and experience gender. Such data would reveal how gender is done instead of only how it is 'said' (Martin 2003). 


\section{References}

Acker, J. (1990). Hierarchies, jobs, bodies: A theory of gendered organizations. Gender \& Society, 4, 139-158.

Acker, J. (1992). Gendering organizational theory. In A. J. Mills, \& P. Tancred (Eds.) Gendering organizational analysis pp. 248-262. Newbury Park, CA: Sage.

Acosta, R. V., \& Carpenter, L. (2006). Women in intercollegiate sport: A longitudinal, national study: Twenty-nine year update, 19772006. Retrieved February 13, 2007, from Web site: http:// webpages.charter.net/womeninsport/.

Ashcraft, K. (2005). Resistance through consent? Occupational identity, organizational form, and the maintenance of masculinity among commercial airline pilots. Management Communication Quarterly, 19, 67-90.

Alvesson, M., \& Skoldberg, K. (2000). Reflexive methodology: New vistas for qualitative research. London: Sage.

Benschop, Y. (1996). De mantel der gelijkheid: Gender in organisaties [The coat of equality: Gender in organizations]. Assen, NL: Van Gorcum.

Bird, S. (1996). Welcome to the men's club: Homosociality and the maintenance of hegemonic masculinity. Gender and Society, 10, $120-132$.

Claringbould, I. (2006). Vrouwen in zicht [Women in view]. Nieuwegein, The Netherlands: Arko Sportsmedia.

Claringbould, I., \& Knoppers, A. (2007). Finding a 'normal' woman: Selection processes for board membership. Sex Roles, 56, 495-507.

Collinson, D., \& Hearn, J. (1996). Breaking the silence: On men, masculinities and management. In D. Collinson, \& J. Hearn (Eds.) Men as managers, managers as men. Critical perspectives on men, masculinities and managements pp. 1-24. London: Sage.

Connell, R. W. (1987). Gender and power. Stanford, CA: Stanford University Press.

Connell, R. W. (2005). Masculinities (2nd ed.). Berkeley, CA: University of California Press.

Connell, R. W., \& Messcherschmidt, J. (2005). Hegemonic masculinity: Rethinking the concept. Gender \& Society, 19, 829-859.

Dellinger, K. (2004). Masculinities in 'safe' and 'embattled' organizations: Accounting for pornographic and feminist magazines. Gender \& Society, 18, 545-566.

Demetriou, D. Z. (2001). Connell's concept of hegemonic masculinity: A critique. Theory and Society, 30, 337-361.

Fairclough, N. (1995). Critical discourse analysis. London: Longman.

Fitzgerald, M., Sagaria, M., \& Nelson, B. (1994). Career patterns of athletic directors: Challenging the conventional wisdom. Journal of Sport Management, 8, 14-26.

Hall, M. A., Cullen, D.,\& Slack T. (1990). The gender structure of national sport organizations. Sport Canada: Occasional papers, vol. 2 (1) Ottawa, Canada: Government of Canada, Fitness and Amateur Sport.

Hatcher, C. (2003). Refashioning a passionate manager: Gender at work. Gender, Work and Organization, 10, 391-412.

Hearn, J. (1999). Men managers and management: The case of higher education. In S. Whitehead, \& R. Moodley (Eds.) Transforming managers: Gendering change in the public sector pp. 123-144. New York: Routledge.

Hoeber, L., \& Frisby, W. (2001). Gender equity for athletes: Rewriting the narrative for this organizational value. European Sport Management Quarterly, 1, 179-209.

Hovden, J. (2000). Gender and leadership selection processes in Norwegian sporting organizations. International Review for the Sociology of Sport, 35, 75-82.

Hughes, C. (2004). IOC 3rd Women and Sport World conference. Retrieved on November 30, 2005 from http://www.wsf.org.uk/ docs/IOC_3rd_World_Conf_report.doc.
Inglis, S. (1997). Roles of the board in amateur sport organizations. Journal of Sport Management, 11, 160-176.

Kanter, R. M. (1977). Men and women of the corporation. New York: Basic Books.

Kerfoot, D. (1999). The organization of intimacy: Managerialism, masculinity and the masculine subject. In S. Whitehead, \& R. Moodley (Eds.) Transforming managers: Gendering change in the public sector pp. 184-199. New York: Routledge.

Kerfoot, D., \& Knights, D. (1998). Managing masculinity in contemporary organizational life: A 'man'agerial project. Organization, $5,65-89$.

Knoppers, A. (2006). The skill levels of men are quite diverse: Gender and coaching. In A. Knoppers, \& A. Anthonissen (Eds.) Making sense of diversity in organizing sport pp. 58-70. Oxford, UK: Meyer and Meyer.

Knoppers, A., \& Anthonissen, A. (2005). Male athletic and managerial masculinities: Congruencies in discursive practices? Journal of Gender Studies, 14, 123-135.

Knoppers, A., \& Bouman, Y. (1998). De trainer als cultuurdrager. [The trainer as a mirror and creator of culture]. In J. Steenbergen, A. Buisman, P. de Knop, \& J. Lucassen (Eds.) Waarden en normen in de sport: Analyse en beleidsperspectief pp. 223-238. Houten: Bohn Stafleu Van Loghum.

Kvande, E., \& Rasmussen, B. (1994). Men in male-dominated organizations and their encounter with women intruders. Scandinavic Journal for Management, 10, 163-173.

Lapchick, R. (2006). The 2005 racial and gender report card. University of Central Florida: The Institute for Diversity and Ethics in Sport.

Lyon, D., \& Woodward, A. (2004). Gender and time at the top: Cultural constructions of time in high level careers and homes. European Journal of Women's Studies, 11, 205-221.

Martin, P. Y. (2001). 'Mobilizing masculinities': Women's experiences of men at work. Organization, 8, 587-618.

Martin, P. Y. (2003). 'Said and done' versus 'saying and doing': Gendering practices, practicing gender at work. Gender \& Society, 17, 342-366.

Martin, P. Y. (2006). Practising gender at work: Further thoughts on reflexivity. Gender, Work and Organization, 13, 254-276.

McDowell, L. (1997). Capital culture: Gender at work in the city. Oxford, UK: Blackwell.

McDowell, L. (2001). Men, management and multiple masculinities in organizations. Geoforum, 32, 181-198.

McKay, J. (1997). MANaging gender. Albany: State University of New York Press.

Messner, M. (2002). Taking the field: Women, men and sports. Minneapolis, MN: University of Minnesota Press.

Meyerson, D., \& Kolb, D. (2000). Moving out of the 'armchair': Developing a framework to bridge the gap between theory and practice. Organization, 7, 553-571.

Moodley, R. (1999). Masculine/managerial masks and the 'other' subject. In S. Whitehead, \& R. Moodley (Eds.) Transforming managers: Gendering change in the public sector pp. 214-233. New York: Routledge.

Moore, M., Parkhouse, B., \& Konrad, A. (2001). Women in sport management: Advancing the representation through HRM structures. Women in Management Review, 16, 51-61.

Nuijten, S., Lucassen, J., \& Van Kalmthout, J. (2004). Verenigingsmonitor 2003, de stand van zaken in de sportvereniging [Sport club monitor 2003: The state of affairs]. Arnhem, The Netherlands: NOC*NSF.

Peters, T., \& Waterman, R. (1982). In search of excellence: Lessons from America's best-run companies. New York: Harper and Row.

Poggio, B. (2006). Outline of a theory of gender practices. Gender, Work and Organization, 13, 225-233. 
Riley, S. (2001). Maintaining power: Male constructions of 'feminists' and 'feminist values. Feminism and Psychology, 11, 55-78.

Rutherford, S. (2001). Any difference? An analysis of gender and divisional management styles in a large airline. Gender Work and Organization, 8, 326-345.

Sagas, M., \& Cunningham, G. (2004). Does having the right stuff matter? Gender differences in the determinants of career success among intercollegiate athletic administrators. Sex Roles, 50, 411-421.

Shaw, S. (2006). Scratching the back of 'Mr. X': Analyzing gendered social processes in sport organizations. Journal of Sport Management, 20, 510-534.

Shaw, S., \& Frisby, W. (2006). Can gender equity be more equitable? Promoting an alternative frame for sport management research, education, and practice. Journal of Sport Management, 20, 483-509.

Shaw, S., \& Hoeber, L. (2003). A strong man is direct and a direct woman is a bitch: Gendered discourses and their influence on employment roles in sport organizations. Journal of Sport Management, 17, 347-375.
Shaw, S., \& Slack, T. (2002). 'It's been like that for donkey's years': The construction of gender relations and the cultures of sport organizations. Culture, Sport, Society, 5, 86-106.

Stol, P. (1995). Speurtocht gewenst: Vrouwelijke trainers! [A search is needed: Women coaches!] Internship report. Utrecht, The Netherlands; Universiteit Utrecht, Tracé Sport, Bewegen en Gezondheid, vakgroep Pedagogiek.

Wacjman, J. (1998). Managing like a man: Women and men in corporate management. University Park, PA: Polity Press.

Weedon, C. (1997). Feminist practice and poststructuralist theory. Oxford: Blackwell.

Wetherell, M., \& Edley, N. (1999). Negotiating hegemonic masculinity: Imaginary positions and psycho-discursive practices. Feminism and Psychology, 9, 335-356.

Whisenant, W., Pedersen, P., \& Obenour, B. (2002). Success and gender: Determining the rate of advancement for intercollegiate athletic directors. Sex Roles, 47, 485-491.

White, A., \& Brackenridge, C. (1985). Who rules sport? Gender divisions in the power structure of British sport organizations from 1960. International Review for the Sociology of Sport, 20, 96-107. 